\title{
Insects attack citrus trees in Al- Qalyubiyah Governorate, Eygypt
}

\author{
Aida S. Kamel \\ Entomology Department, faculty of science, Benha University.
}

\begin{abstract}
This study was aimed to determine the recent status of insect pests infest the citrus trees (Baladi and Navel Orange) at Qalyubiyah governorate, Egypt. Study was conducted during visiting two orchards in Tukh area twice a month for nineteen continuous months. Seasonal abundance of the dominant species of insects pests infesting citrus trees and their natural enemies were also investigated.

Thirteen insects pests species were found. They were belonging to families: Aphididae, Coccidae, Margarodidae, Diaspididae, Anthomyi, Aleyrodidae, Thripidae and Drosophilidae. Aphids were the most common pest attacking citrus trees. Its peak of abundance was between March and first week of April followed by significant numbers of scale insects and leaf miner, which were found in most months of the year. The natural enemies of citrus pests species were belonging to these taxonomic groups: Neuroptera, Hemiptera and Coleoptera, Hymenoptera and Acari.
\end{abstract}

Key words: Citrus trees, Citrus pests, Natural enemies

\section{INTRODUCTION}

Citrus trees make great landscape trees, but when grown for fruits purposes there are many insects pests attack and cause fruits to be inedible. Identifying these pests is the first step for producing healthy, delicious fruits.

Buker et al.,2006 were concluted that Citrus trees is affected by numerous species of insects pests, mites, and disease pathogens that infest the leaves, flowers, bark, fruits, and branches of citrus. The most common sucking pests attack citrus are aphids, mealy bugs, scales insects and mites. These pests appear on the leaves, stems and fruits in clusters and feed on the sweet sap by inserting a needle-like sucking tube into the plant and drawing out the juice. After the sap has been used by the insects, it is excreted as honeydew, which forms the base on which a black fungus grows. This fungus is known as sooty mould and its presence reduces photosynthesis and discolours affected fruit. Honeydew is used as a food source by ants, which will actively transport the insects (aphids, mealybugs and scales) to position them on the plant (farm them). Ants may spread sapsucker infestations between plants via underground tunnels. As aphids, mealybugs, scales and mites congregate in hidden places or on the lower leaf surface. Due to great damage can be done by scale insects not only by sucking the plant sap but also due to excretion of large amount of honey dew that rich in sugar and nitrogenous components, so give good media to sooty mold fungi that increase the inhibition of photosynthesis qualities of plants (Radwan., 2003). In addition the insect secretion of toxic saliva that resulted in malformed leaf and shoot growth .These characteristic symptoms Similar to damage caused by viruses (fisheries \& Foresty., 2008). 'Aphid' is the common name for the insects belonging to the superfamily Aphidoidea, within the order Hemiptera. There is virtually no part of terrestrial plants that are not attacked by an aphid, either above or 
below ground; they can even feed on bark. The reason lies in the amazing biological features that these tiny insects have evolved to maximize their performances as phytophagous insects. The combination between specific feeding and reproductive habits concurred in making the aphids one of the most economically important groups of pest in agriculture. In temperate climates they are considered the most important insect pest (Minks and Harrewijn., 1989), especially in those cases where their attack is associated with the transmission of phytopathogenic viruses

Often during an aphid infestation, the leaves appear to be dripping sap from the underside of the leaves. This is actually an excretion from the aphids and is called honeydew. It often drips onto other leaves, other plants and on to the ground. The honeydew then becomes an attractant to ants, which feed on it. In most cases the ants are only symptoms of the honeydew and are not actually attacking or hurting the tree.

Guerrieri, et al.2008 discussed that aphid feed on a phloem sap by extremely efficient mouthparts modified into long and flexible styles. In order to reach plant phloem, aphids must overcome plant defenses, either physically and/or chemically. However, plants respond to aphid attack by activating defense genes that lead to the production of physical barriers and/or chemical toxic compounds (direct resistance). In addition, attacked plants can attract the natural enemies of aphids by releasing specific volatile compounds (indirect resistance). We can take advantage of these different types of resistance in order to enhance the sustainable control of these phytophagous insects.

Ants play an important role in the destruction caused by aphids. Certain species of ants protect aphids from enemies, shelter them from bad weather, tend their eggs, and carry them from one host plant to another to feed. Such aphids are often called ant cows, because the ants eat the honeydew they produce, and even "milk" the aphids by stroking them with their antennae to increase the flow of honeydew.

The relative abundance of aphidiine parasitoids on aphids infesting orange and tangerine trees was studied in southern Greece (Nea Kios) in 1996 and 1997. A. gossypii constituted the largest part of the aphid population and was the only species parasitized. B. angelicae and A. colemani were the most abundant parasitoid species.

The parasitization rate differed among the parasitoid species. B. angelicae had the highest colonization rate in centrally located and large host (A. gossypii) groups, whereas $A$. colemani was found in more isolated and relatively small host groups. The percentage of parasitism by $B$. angelicae was high mainly in large host groups, when $B$. angelicae was the only parasitoid present. However, in cases of coexistence of aphidiine parasitoids on aphid with hyperparasitoids, in the same sampling unit, the percentage of parasitism was relatively low (Kavallieratoes., 2002).

The small leaf miner moth or the citrus leaf miner (CLM), Phyllocnistis citrella (Lepidoptera: Gracillariidae: Phyllocnistinae). It is potentionally a series pest of citrus and related Rutacae and some ornamental plants (Beattie, 1989). Symptoms of infestation include. 1- Leaf with serpentine mine, usually on ventral surface. 2curling of leaves. 3-epiderms appearing as silvery film over leaf mine. 4- pupation chamber near leaf margin the edge of which is rolled over and exposed portion of chamber with distinct orange color. 5- succulent branches of green shot may also attacked (Beattie 1989, Pandey and pandey 1964).

Fruit fly attacks citrus causes economic yield losses in Nigeria. The high demand for sweet oranges in recent times necessitates the need to develop control strategies that can reduce fruit fly damage and ameliorate yield. This can be achieved by identifying the diversity, abundance and spread of major sweet orange fruit flies. (Vincent et al., 2008). 
Most soft scale insects can reproduce sexually or parthenogenically. So many different scale insects can be found in scale colonies sexual dimorphisms. Apparent male is slender, smaller, lighter and winged with vestigial mouth parts in dense infestation male appear not only on the lower surface but also attack the upper surfaces, twigs, stems, and even roots. It is very difficult to remove them from the fruits.

Brown soft scale insects are a common problem on citrus trees, as well as many other types of trees. Soft scale insects are small, non-mobile insects that attached themselves to the wood, foliage and sometimes the fruits. Scales are most common on the new tender woody growth. When adult scale is attached to the tree, it often appears as crusty or waxy bumps on the tree. Often it is mistaken for part of the tree's own growth, but it is actually an insect. The scale sucks sap from the tree and causes the leaves to turn yellow and drop. Often a sticky substance can be found near the scale or on the leaves. This is a secretion from the scale called honeydew and often acts as an attractant for ants or as a growing source for sooty mold.

In the spring or mid-summer, small, almost invisible nymphs emerge from under the female shells and move to infect new areas of the tree. This is the only time in the life cycle of scale insect moves on the tree.

Thrips, Heliothrips haemorrhoidalis (Bouche) were collected from flowers, immature and mature fruit from commercial citrus orchards mainly in the Northland region of New Zealand. (Blank and chilli., 1971) were commonly found on mature fruits of all citrus varieties where their feeding activity caused a whitening of the rind.

Fruits of Valencia orange were particularly susceptible to damage by this species of Thrips, with mandarin, navel orange, and tangelo also damaged.

\section{MATERIAL AND METHODS}

Samples of various pests of insects were collected to study the population dynamic of pests attack citrus trees. Nearly 160 trees $2.5 \mathrm{~m}$ in height located at Tukh Qalyubiyah 80 trees per each orchard (Baladi and Navel orange). The samples were collected twice a month between January 2009 and July 2010. 10 infested orange leaves were collected randomly from orange orchards. The leaves were packed in well ventilated bags and monitored daily by binocular microscope.

Two method were used for count the Aphids:

1) Yellow sticky trap covered with glue and cooking oil were hanging randomly in citrus trees.

2) The whole leaf area was measured for different sizes of leaves. The average of counted numbers of aphids $/ \mathrm{cm}^{2}$ was taken by dividing the number of aphids counted / the average leaf area.

Other samples were investigated by binocular and images were taken by the digital camera (Samsung, 7.2 mega pixels). The main climatic factors Maximum and Minimum Temperature, Maximum \& Minimum Relative humidity (R.H.) and wind speed ,Rain fall were recorded at Qalyubiyah Governorate with the aid http://wwww.wheather on line.co.uk/Egypt was recorded in Table(1) .

Precipitations in winter months specially December, January, and February were recorded, where the maximum Rain fall 7, 8 and $8 \mathrm{~mm}$ respectively, while there were no precipitations in summer months. Identification was done by using different Keys such as (Ezzat, 1985), (Ezzat \& Husein, 1967), (Homan and William, 1984) and (Miller et al., 2006) 
Table 1: Show the variation of climatic factors during the period of investigation

\begin{tabular}{|c|c|c|c|c|c|}
\hline Months & $\begin{array}{l}\text { Max. } \\
\text { Temp. }\left[{ }^{\circ} \mathrm{C}\right] \quad \text { (January } \\
\text { 2009-July 2010) }\end{array}$ & $\begin{array}{lr}\text { Min. } & \text { Temp. } \\
{\left[{ }^{\circ} \mathrm{C}\right]} & \text { (January } 2009 \\
- \text { July 2010) }\end{array}$ & $\begin{array}{ll}\text { M ax. } & \text { Relative } \\
\text { humidity } & \text { R.H \% } \\
\text { (January } & 2009- \\
\text { July 2010) }\end{array}$ & $\begin{array}{l}\text { 'Min.. Relative } \\
\text { humidity } \\
\text { R.H \% (Jan. } \\
2009-\text { July } \\
2010\end{array}$ & $\begin{array}{l}\text { Wind-force per } \\
\text { Day (January } \\
2009 \text { - July 2010). }\end{array}$ \\
\hline Jan. 2009 & 21.0 & 11.9 & 66 & 30 & 11.7 \\
\hline Feb " & 22.0 & 12.7 & 57 & 31 & 14.1 \\
\hline Mar. " & 23.4 & 13.6 & 61 & 37 & 14.1 \\
\hline Apr. " & 28.4 & 16.7 & 59 & 30 & 14.2 \\
\hline May. " & 31.3 & 20.2 & 59 & 29 & 14.8 \\
\hline Jun. " & 36.1 & 24.0 & 56 & 34 & 14.5 \\
\hline Jul. " & 35.5 & 24.0 & 65 & 50 & 13.2 \\
\hline Aug." & 34.4 & 24.7 & 66 & 47 & 11.4 \\
\hline Sept. " & 33.0 & 23.4 & 61 & 51 & 14.2 \\
\hline Oct. " & 31.2 & 21.4 & 66 & 27 & 11.9 \\
\hline Nov. " & 24.5 & 15.6 & 75 & 61 & 11.4 \\
\hline Dec. " & 22.2 & 14.2 & 81 & 33 & 13.8 \\
\hline Jan. 2010 & 24.2 & 12.8 & 64 & 22 & 12.2 \\
\hline Feb " & 21.9 & 14.2 & 70 & 24 & 13.0 \\
\hline Mar. " & 24.2 & 15.7 & 62 & 43 & 14.6 \\
\hline Apr. " & 29.2 & 17.8 & 55 & 25 & 14.5 \\
\hline May " & 32.2 & 20.3 & 59 & 39 & 14.8 \\
\hline Jun. " & 35.7 & 23.9 & 58 & 31 & 14.6 \\
\hline Jul. " & 35.0 & 24.1 & 62 & 28 & 14.3 \\
\hline Average & $: 28.9^{\circ} \mathrm{C}$ & $: 18.8^{\circ} \mathrm{C}$ & $60.2 \%$ & $32.3 \%$ & $13.6 \mathrm{kph}$ \\
\hline
\end{tabular}

\section{RESULTS AND DISCUSSION}

The survey was carried out on citrus trees in Tukh area at Qaliubyia Governorate from January 2009 to July 2010, twice monthly. The obtained data were listed in tables $(2,3)$ and illustrated in figures (1-18). During the studies the two orchards are rich with pests of 716 individuals on baladi and 646 individuals on navel orange table (3) where the total of thirteen collected pests belonging to families: Aphididae, Coccidae, Margarodidae, Diaspididae, Anthomyiidae, Aleyrodidae, Thripidae and Drosophilidae were found within the study site.

The most common pest is green aphid Aphis gossypii $(76.53 \& 71.1 \%)$ on both baladi and navel orange of total collected pests its natural enemies had not been able to keep the pest population at low level, then leaf miner Pegomyia hyasayami (15.6\& $19.8 \%$ ), Iceryae seychelarum ( $2.09 \& 2.16 \%$ ), Aonidella Orientalis (1.6 \& $1.94 \%)$, Parlatoria Zizphus (1.3\&1.7\%) Ceratoplastes floridensis (0.7\& 1.29\%), Ceratoplastes rusci $(0.4 \& 0.43)$, Iceryae pruchasi $(0.41 \& 0.43)$, Bemisia tabacii (0.69 \&0.43\%), Coccus hespereidum (0.0\&0.43\%). A Thrips sp. its numbers were few in comparative with other pests collected leaves while its scarring on the fruits were found Fig.(16). and Drosophilla sp. were (0.0 \&0.2).

Result of seasonal abundance of Aphis gossypii through the period of investigation from January 2009- July 2010 (Fig.1) showed that its peak was in March and April (spring season). This due to moderate temperature and relative humidity where the aphid attack the flowers and growing shoot. While clear variation of other pests in table (3), due to extreme temperature might explain this fluctuation. Where Abul Nasr et al., 2002) were studies the population density of the citrus red scale infesting naval orange leaves in 7 governorates of lower Egypt., they concluded that the population density varied with the governorates, being lowest in Alexandria and Beheira. The insect had 3-4 annual population peaks. These were indicated. High temperature and low relative humidity accelerated the development of the insect. 


\section{Diagnosis:}

Aphis gossypii Family Homoptera Fig. 2:

It was tiny, soft bodied pear-shaped insect injurious to citrus leaves. Some are wingless; others have two pairs of transparent or colored wings, the front pair longer than the hind pair. The legs are pale with the tips of the tibiae and tarsi black, the cornicles also are black, . its color vary from light green mottled with dark green was most common, but also occurring were yellow pale green \& darkr green forms Fig. (3) during visiting the orange field, we noticed some aphid on the leaves change in color to light brown or grey papery mummies and become swollen Fig. (4), this is indicated to aphids have been attacked by a parasitic wasp and are quite dead. The female parasitic wasp inserts an egg into the aphid when it hatches, the larva feeds on the aphid internally and the new adult has chewed its way out. This agree with the finding of, (Beavers et al., 1971).

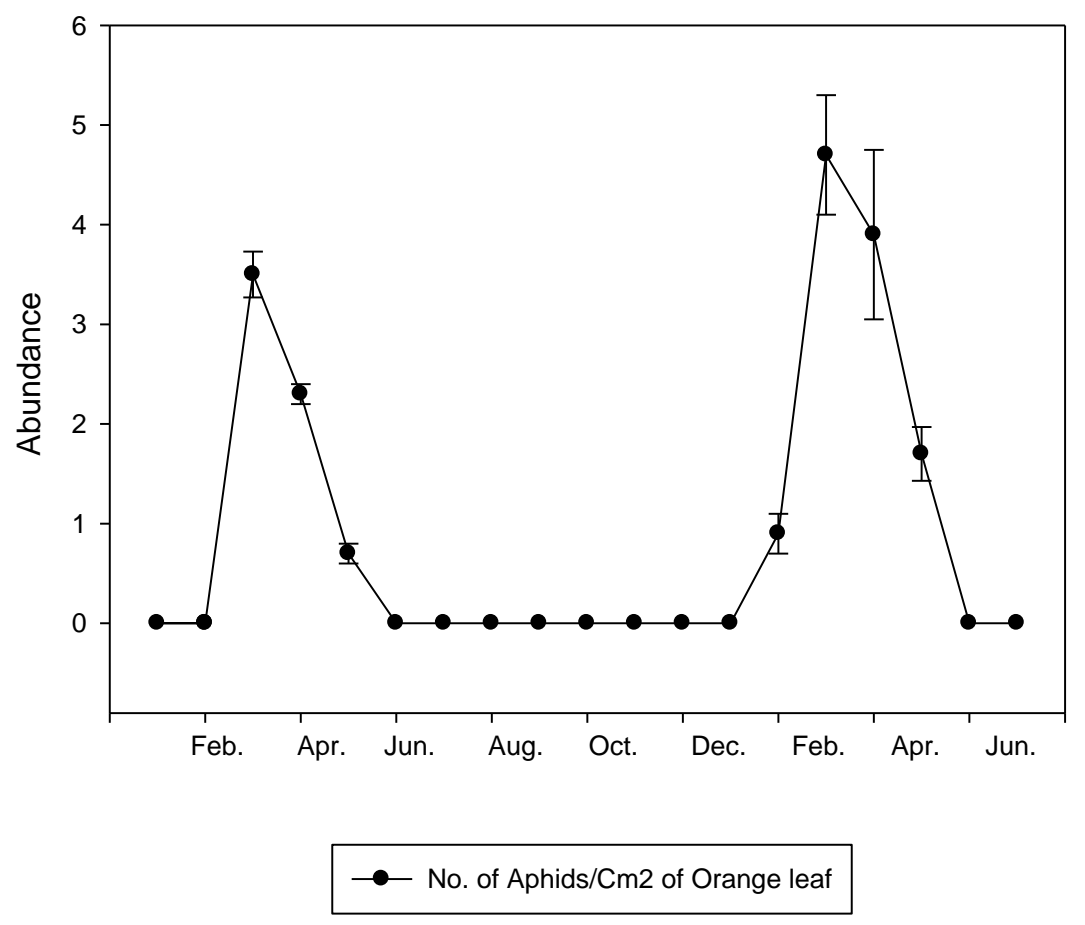

Fig. 1: Show the seasonal abundance of aphid during January 2009 -July 2010.

\section{Iceryae seychellarum, Family: Margarodidae}

Yellowish white adult female enclosed in very tough spherical cyst composed of very thin layer, adult female look like a hairy ball with a purpish body contents antennae short and stout, eye will developed Fig. (5) the wax scale insects Iceryae seychelarum infested baladi and navel orange from February to August and its abundance in June and July, and become most series soft scale insect infest orange.

Pulvenaria psidii Family : Coccidae Fig. (6) Soft scale without armored scale microscopically with abdominal spiracle anus with anal rings and plates, legs usually will developed, male head with fairly distinct neck ( family coccidae) Green in color, flat, with large discoidal pores, extending from anal plates to head. 
Coccus hesperidium Linnaeus, Family : Coccidae Fig.(7)

Brown soft scale, adult female scale is yellowish brown with transparent area and brown spots, oval ,slightly convex in dense population ,2-3 mm long and 1.5-2 mm wide with spine- shaped dorsal setae and 4 apical setae at anal plate

Bemisia tabaci whitefly, Family: Aleyrodidae Fig. (12).

A whitefly has a pale yellow body with white, translucent wings. It is most commonly found feeding on the underside of the tree's leaves. The whiteflies also lay their eggs on the underside of the leaves. When the eggs hatch, the juveniles are small oval, almost transparent larva, which attach themselves to the underside of the leaves and begin sucking the sap from the leaves. In this study the orange leaves were investigated and found black parasitoid pupae of white flies which could not be identified.

Iceryae pruchasi family: Margarodidae (Cottony cushion scale) Fig. (10).

It is originally from Australia and they are between long 7-9 mm, with reddish brown bodies covered with a thick white wax. Adult female have characteristic large elongated white fluted eggs case projecting from one end of the reddish upper body surface and long dark legs.

Ceroplastes floridensis family: Coccidae (wax scale insects) Fig. (11)

Whitish in color with one dorsal plate and 6 lateral plates without $\mathrm{H}$ shaped ridges.

There was another common problem on citrus leaf miner were cause serpentine tunnels that have silvery appearance on the leaf surface caused by larvae (Diptera, Anthomyiidae), Fig. (13), where (Heppner., 1995) indicated to the silvery appearance of the mines were due to air and condensed water vapour trapped in the mines.

\section{Ceratoplastes rusci Family: Coccidae (fig wax scale) Fig. (14)}

Fig. wax scale, Ceroplastes rusci L. is one of the scale insects species infest citrus trees but in few numbers in relation to other pests in both baladi and Navel orange this is may be due to the absence of fig trees in the vicinity of citrus trees in this site .This scale is deeply encased in pinkish-gray wax, which is divided into three wax plates on each side with additional plates at the anterior and posterior ends. The single large dorsal plate has a central nucleus. Dorsal and lateral plates are separated from each other by dark red lines which are the color of the scale's body beneath the wax. The anterolateral and mediolateral plates have some white wax which indicates the stigmatic wax bands. In contrast, (Talhouk., 1975) reported that the fig wax scale is the most common scale insects in Jordan and presence of this scale in the Mediterranean region (Algeria, Cyprus, Egypt, Greece, Israel, Italy, Lebanon, Morocco, Spain, Tunisia and Turkey) and Argentina.

\section{Aonidella orientali Family: Diaspididae, Fig. (9)}

Scale cover of adult female $1.5-2.6 \mathrm{~mm}$ diameter, circular to oval flat off white to pale brown, or yellow, with dark brown exuviae Beneath the scale cover the adult female insect is pyrifom initially with maturity of sub circular and becoming moderately sclerotized around margin. Scale cover of male similar in color to the female but smaller elongate oval with subminal yellow exuviae.

\section{Palatoria ziziphi Family : Diaspididae, (black parlatoria scale) Fig. (17)}

The Species has become the most important pest of citrus in Egypt-Parlatoria ziziphus (Lucas) or Ebony scale is one of five-Parlatoria species known to attack citrus and many area of the world it is considered a major pests of citrus. The skin of the body wall is hardened by wax like secretion which is either incorporated into the skin. The armor of the female black parlatoria scale appear to be flat, shield-shaped 
and about 1.25 to $2.0 \mathrm{~mm}$ long ,the first exuviae is lightly convex and is rectangular with rounded angle. There is usually fringe of white around the posterior perimeter of the armor. The male is flat, elongate white and about 1/3 the size of the male. Several kinds of natural enemies including parasites, predators were found belong to Neuroptera, Chrysopidae (Lacewings, Chrysoperla carnea) larvae, Fig. (8) and Coleoptera, Coccinellidae lady bird coccinella undecim punctata and Coccinella septempunctata Linnaeus and parasites belong to Hymenoptera Pnigalio sp. Fig, (15), parasite of citrus leafminer and Aphidius colemani, belonging to Braconidae, Hymenoptera, aphid parasitoid Fig. (18) and predator mites Amblyseius spp, belonging to Phytoseiidae, Acari (predator of thrips) were identified in this studies.

The result agree with conclusion of (Beavers et al. 1971) they reported that, lace wing larvae can consume 300-400 aphids and are usually best suited for high aphid population situations. If there is excess food, more prey will be killed than consumed, on the other hand, adult feed only on honeydew, nectar and pollen. Also ladybeetles feed on aphids to maintain egg production. Adult aphid predators seek out aphids and lay eggs near the colony. After about 2 - 3 days the eggs hatch into tiny, bright-orange larvae which immediately begin feeding on aphids and are attracted by the smell of honeydew. This was proved by (Khan, 2001) who reported that numerous species of Coccinellids are major biological agents of pests such as aphids, mealybugs, scale insects, thrips and mites in all parts of the world.

Amblyseius spp. mature adult are shiny, transparent to cream-colored, and some have a bit of orange markings. They have a more elongated body shape and are about $0.45 \mathrm{~mm}$ long.. The immature stages look like the adults; they are smaller in size and move more slowly. The eggs are glossy transparent to cream-colored and oval about $0.15 \mathrm{~mm}$ long. Differentiation of the various Amblyseius species is very difficult in the field and requires assistance from a skilled laboratory technician. http/:www.infoet-biovision.org/default/ct/296/rec.

Table 2: show the collected pests belonging to different taxonomic groups during the period of investigation

\begin{tabular}{|c|c|c|c|c|c|c|}
\hline eries & pests & family & order & $\begin{array}{l}\text { natural enemies } \\
\text { parasites } \& \\
\text { predators }\end{array}$ & family & order \\
\hline 1 & Aphis gossypii & Aphididae & Homoptera & $\begin{array}{l}\text { Coccinella undecim } \\
\text { punctata } \\
\text { Chrysopa carnea }\end{array}$ & $\begin{array}{l}\text { Coccinellidae } \\
\text { Chrysopidae }\end{array}$ & $\begin{array}{l}\text { Coleoptera } \\
\text { Neuroptera }\end{array}$ \\
\hline 2 & Pulvenaria pisidi & Coccidae & Homoptera & & & \\
\hline 3 & Iceryae pruchsi & Margarodidae & $x_{2}$ & & & \\
\hline 4 & Iceryae seychelarum & $"$ & $"$ & & & \\
\hline 5 & $\begin{array}{l}\text { Ceratoplastes } \\
\text { floridensis }\end{array}$ & Coccidae & Hemiptera & Aphidius colemani & Braconidae & Hymenoptera \\
\hline 6 & Ceratoplaste rusci & " & $"$ & & $"$ & $"$ \\
\hline 7 & Palatoria zizphi & Diaspididae & $"$ & & & \\
\hline 8 & Aonidella orientali & Diaspididae & $"$ & & & " \\
\hline 9 & Pegomyia hyasayami & Anthomyiidae & Diptera & Pnigalio sp. & & Hymenoptera \\
\hline 10 & Bemisia tabasi & Aleyrodidae & Homoptera & & & \\
\hline 11 & Coccus hesperidum L. & coccidae & Hemiptera & $\begin{array}{l}\text { coccinella } \\
\text { septempunctat }\end{array}$ & Coccinellidae & Coleoptera \\
\hline 12 & thrips sp. & Thripidae & Thysanoptera: & $\begin{array}{l}\begin{array}{l}\text { Predatory } \\
\text { Amblysei }\end{array} \\
\end{array}$ & Phytoseiidae & Acari. \\
\hline 13 & Drosophila sp. & Drosophilidae & Diptera & & & \\
\hline
\end{tabular}


Table 3: Comparative relative abundance of insect pests on Baladi and Navel orange during the period of investigation.

\begin{tabular}{|c|l|l|l|l|l|l|}
\hline series & pests scientific name & family & Baladi & \% & navel & \% \\
\cline { 4 - 7 } & & & No. & & No. & \\
\hline $\mathbf{1}$ & Aphis gossypii & Aphididae & 548 & 76.53 & 330 & 71.12 \\
\hline $\mathbf{2}$ & Pulvenaria pisidi & Coccidae & 3 & 0.41 & 1 & 0.23 \\
\hline $\mathbf{3}$ & Iceryae pruchsi & Margarodidae & 3 & 0.41 & 2 & 0.43 \\
\hline $\mathbf{4}$ & Iceryae seychelarum & - & 15 & 2.09 & 10 & 2.16 \\
\hline $\mathbf{5}$ & Ceratoplastes floridensis & Coccidae & 5 & 0.7 & 6 & 1.29 \\
\hline $\mathbf{6}$ & Ceratoplastes rusci & " & 3 & 0.4 & 2 & 0.43 \\
\hline $\mathbf{7}$ & Palatoria zizphus & Diaspididae & 10 & 1.3 & 8 & 1.72 \\
\hline $\mathbf{8}$ & Aonidella orientali & Diaspididae & 12 & 1.6 & 9 & 1.94 \\
\hline $\mathbf{9}$ & Pegomyie hyasayami & Anthomyiidae & 112 & 15.6 & 92 & 19.83 \\
\hline $\mathbf{1 0}$ & Bemisia tabasii & Aleyrodidae & 5 & 0.69 & 2 & 0.43 \\
\hline $\mathbf{1 1}$ & Coccus hesperidum L. & coccidae & 0 & 0 & 1 & 0.23 \\
\hline $\mathbf{1 2}$ & Thrips sp. & Thripidae & 0 & 0 & 1 & 0.23 \\
\hline $\mathbf{1 3}$ & Drosophila Sp. & Drosophilidae & 0 & 0 & 0 & 0 \\
\hline & & total & 716 & $100 \%$ & 464 & $100 \%$ \\
\hline
\end{tabular}

\section{AKNOLEDGMENT}

I am grateful to Dr. Reda F. Bakr ,professor in Entomology department ,faculty of Science ,Ain Shams university for his encouragement and offered advices,also I extend my gratitude to Dr. Rawda M. Badawy Taxanomist in entomology department, faculty of science, Ain Shams University who has provided facilities to identification of the collected pests. My thanks to Dr, Hany Abdel salam .zoology department Benha University who had offered staticalal advice and taking images of the pests.

\section{REFERENCES}

Abul Nasr, S.; Swailem, S. and Ahmed, N. M. (2002). Seasonal fluctuation of the citrus red scale insects Anoidiella aurantii (Maskell). in certain regions of lower egypt (Hemiptera,Homoptera Diaspididae ) Agricultural Research Review (Egypt).

Beattie, G. A. C. (1989). Citrus leaf miner. NSW Agric. \& Fisheries, Agfact, H2. AE.4:1-4.

Beavers, J. B.; Shaw, J. G. and Hampton, R. B. (1971). Color and Height Preference of the Citrus Thrips in a Navel Orange Grove Journal of Economic Entomology, Volume 64, Number 5, 15 October 1971, pp. 1112-1113(2)

Blank R. H.; Gill, G. S. C. (1997). Thrips (thysanoptera: Terebrantia) on flowers and fruit of citrus in New Zealand. New Zealand Journal of Crop and Horticultural Science Volume 25, Issue 4 December 1997, pages 319 - 332.

Buker, V. R.S. and Manner, H.I. (2006). Citrus species. Elevitch. C.R. and Smith, Easton 2.1. Hawaii. Hōlualoa, (PAR), Resources Agriculture Permanent Agroforestry. Island Pacific for Profiles S. pecies (ed.). C. R. Elevitch, In: http://www.traditionaltree.org 
Ezzat, Y. M. (1958). Maconellicoccus hirsutus (Green), Anew genus, with redescription Of the species Bull. Soc. Entomo. Egypt.XLII: 337.

Ezzat, Y. M. (1958) .Classification of the scale insects; Family Diapidide Bull. Soc. Entomo. Egypt .XLII: 235-253

Ezzat,Y. M. and husseni (1967). Redescription and classification of the families coccidae inUAR (Homoptera: Coccidae) Bull. Soc. Entomo. Egypt LI 359425.

Fisheries \& Foresty (2008). Australian insect common names Australian vernment. Department of Agriculture http:/www.entomo.csiro .au/aicn /index .htm.

Guerrieri, Emilio and Digilio, Maria Cristina (2008). 'Aphid-plant interactions: a review', Journal of Plant Interactions, 3(4): 223 - 232

Hamon, A. B. and Williams, M. L. (1984). Arthropods of Florida \&Neighboring land area ths soft scale insects of floida (Homoptera: coccoidea: coccoidae) Floidda Depart. of Agric. 4 consumer service, Vol,11:194pp

Heppner JB. (1995). Citrus leaf miner .Lepidoptera: Gracillriidae) on fruits in Florida. Florida Entomologist , 78 (1) :183-186.

Kavallieratos Nickolas G.; Athanasiou Christos G.; Stathas Gerrge J. and Tomanovic Zeljko (2002). Aphid parasitoids (Hymenoptera: Braconidae: Aphidiinae) on citrus: Seasonal abundance, association with the species of host plant, and sampling indices Phytoparasitica2002, vol. 30, nº 4, pp. 365-377 [13 page(s)

Khan I. (2001). Aspects of the biology of the ladybird beetle Stethorus vagans (Blackburn) (Coleoptera: Coccinellidae). Ph. D Thesis. University of Western Sydney, New South Wales, Australia, 183pp.

Minks, AK. and Harrewijn, P. (1989). Aphids: their biology, natural enemies and control Elsevier, New York Fruits 63 (2008) 145-153 DOI: 10.1051/fruits: 2008004

Natural enemies. http// :www.infoet-biovision.org/default/ct/296/rec.

Noyes, J. S and Hayat, M. (1994). Oriental mealy bug parasitoids of Anagyrini oh the (Hymenoptera :Enchyritidae) CAB international: Wallingford

Pandey, N. D. and Pandey, Y. D. (1964). Binomics of Phlloconistis citrallae Stt. ( lepidoptera ,Gracillariiidae ) Indian . J. Ent., 26:417 - 423.

Radwan S. A. (2003). Toxocological studies on some scale insects infested mango and guava trees. ph. D. faculty of Agriculture Cairo Univ.

Reda F. A. Baker; Rawda M. Badwy; Saber F. Mousa; Laila, S. Hamooda and Sahar A. Attaia (2009). Ecological and Taxonomical studies on the scale insects that infest mango trees at Qaliobiya governorate Egypt. Acad. J. Biolg. Sci., 2(2):69-89.

Talhouk AMS. (1975). Citrus pests throughout the world. Ciba-Geigy Agrochemicals, Basel, Switzerland. Technical Monograph No. 4. 21 p.

Vincent C. Umeh; Loyd E. Garcia and Mark De Meyer' (2008). Fruit flies of sweet oranges in Nigeria: species diversity, relative abundance and spread in major producing areas. Fruits 63 (2008) 145- 153.

Weather on line (2010). http://wwww.wheather on line.co.uk/Egypt. [Accessed 07/2010]. 


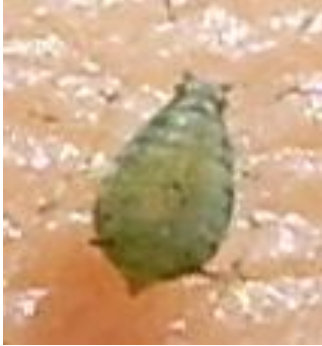

Fig. 2: Aphyis gossypyi

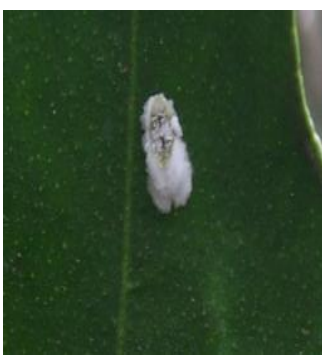

Fig. 6: Pulvenaria psidii

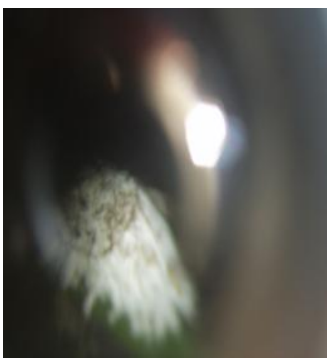

Fig.10: Iceryae Pruchasi (cottony cushion scale)

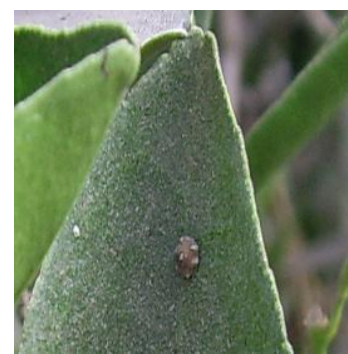

Fig.14: Ceroplastes rusci Fig wax scale

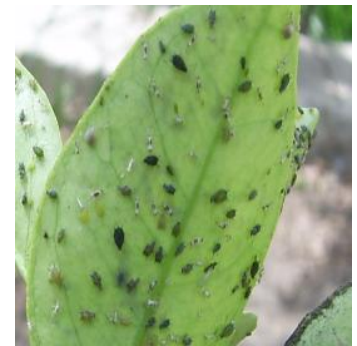

Fig. 3: Varity of color of Aphis gossypii

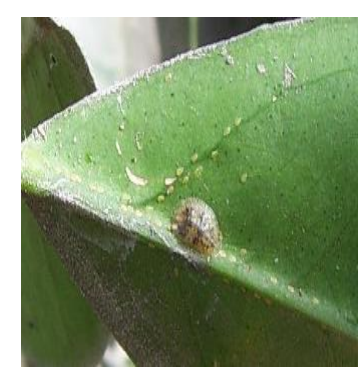

Fig.7: Coccus hesperedium and their eggs

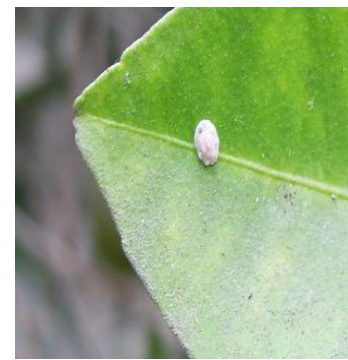

Fig.11: Ceratoplastes floridensis

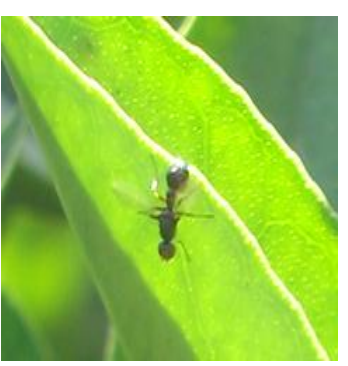

Fig.15: Parasite of Leaf miner

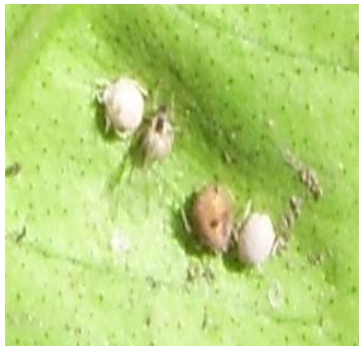

Fig. 4: Parasitoid aphid (mummies)

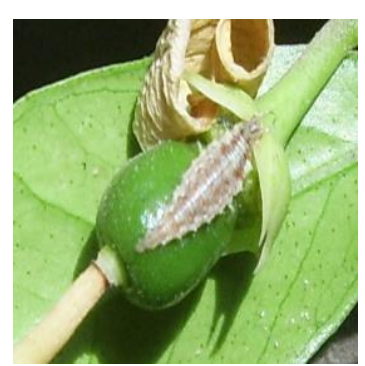

Fig. 8: Lace wing Chrysoperia

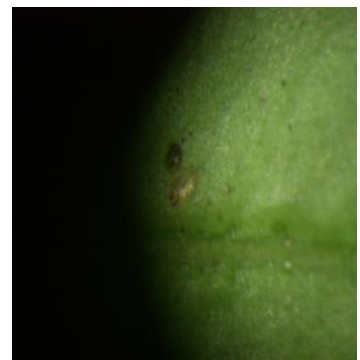

Fig. 12: white fly pupa and parasitoid pupa

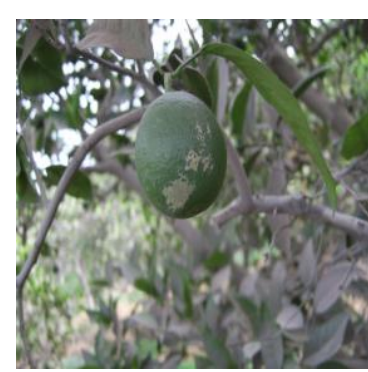

Fig. 16: Scarring on Fruit Caused by Feeding by Thrips

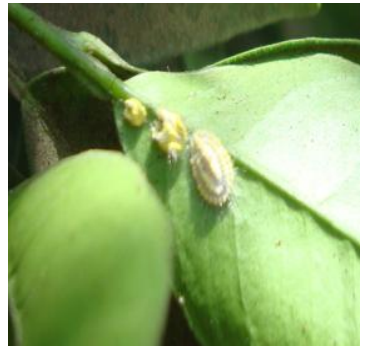

Fig. 5: Iceryae seychelarum

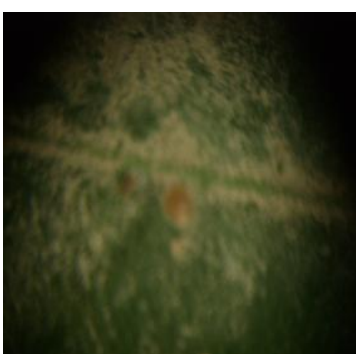

Fig. 9: Aonidella orientali

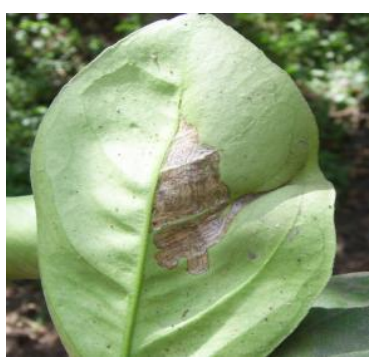

Fig. 13: Serpentine caused by leaf miner

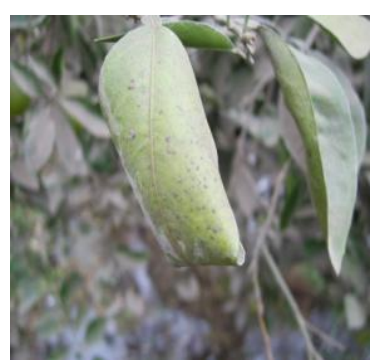

Fig.17: Palatoria ziziphi

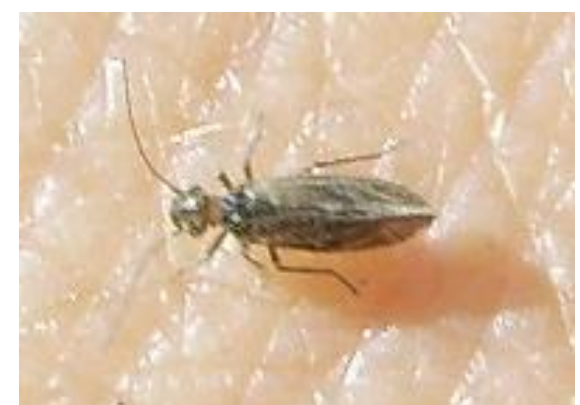




\section{ARABIC SUMMARY}

\section{ألأفات التى تهاجم أشجار الموالح في محافطة القليوبية \\ عايدة سعيد كامل \\ قصم علم الحشر ات ـ كلية العلوم - جامعة بنها}

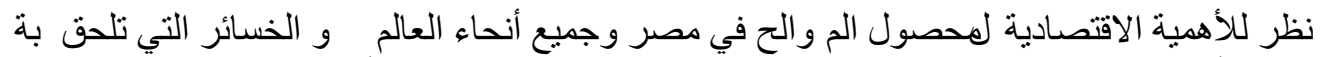

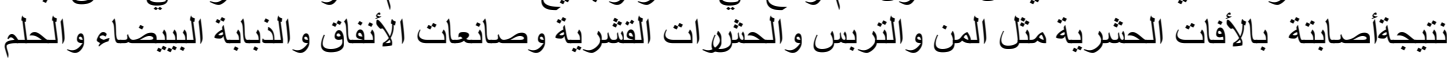

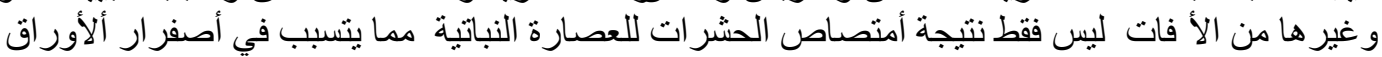

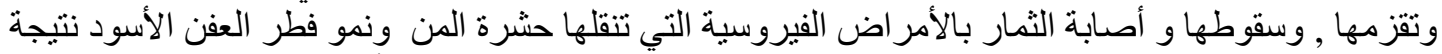

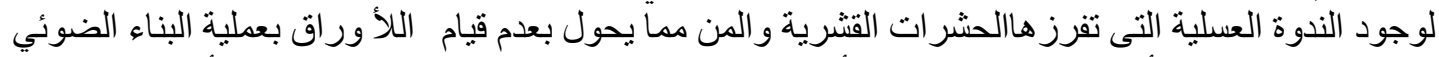

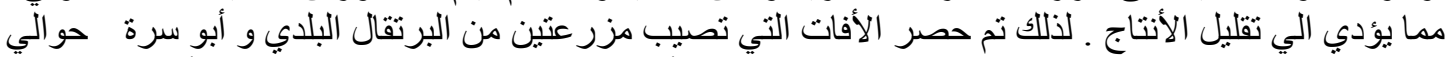

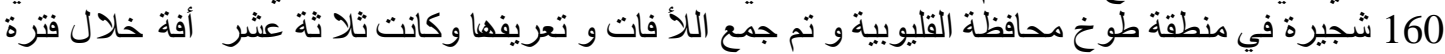

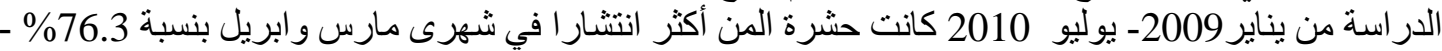

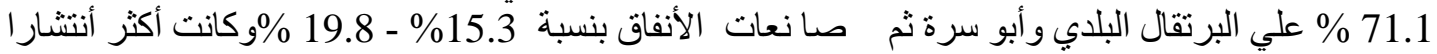

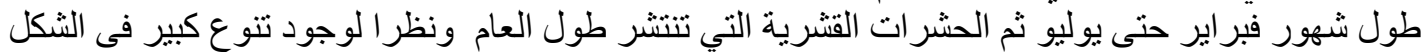

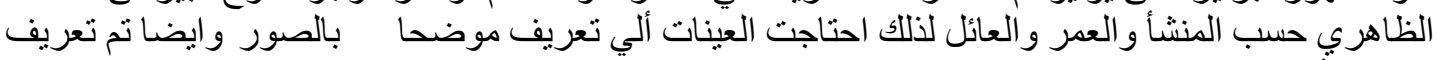
بعض الأعداء الطبيعية من مفترسات وطفيليات وقر اد وجدت فئ المزر عتين. 